\title{
Corporate Tax Planning: A Study On Corporate Effective Tax Rates of Malaysian Listed Companies
}

\author{
Rohaya Md Noor ${ }^{1}$, Nur Syazwani M. Fadzillah and Nor'Azam Mastuki ${ }^{1}$
}

\begin{abstract}
This study attempts to examine corporate effective tax rates (ETRs) of Malaysian public companies listed on Bursa Malaysia during official assessment system and self assessment system tax regimes. The objective is to examine the level of corporate ETRs during official assessment system and self assessment system tax regime and. To achieve the objective, this study uses pooled sample data of $\mathbf{3 1 6}$ companies for the years 1993 to 2006. In determining the two tax regime, the investigation period is classified into two, where the period from 1993 to 2000 represents the official assessment system tax regime whereas the period from 2001 to 2006 represents the self assessment system tax regime. This study finds that corporate ETRs are below the statutory tax rate (STR) in both tax regimes. Moreover, this study reveals that ETRs during the self assessment system tax regime is lower than the official assessment system tax regime. Additionally, this study also examines the determinants of corporate ETRs during both tax regimes. The result supports political cost theory which suggests that larger companies endure higher ETRs. Besides that, lower ETRs are significantly related to highly leverage companies, greater investment in fixed assets and lower investment in inventory. This study also finds that companies with higher return on assets face lower ETRs. Further, sector analysis are carried out to provide the evidence for the variability of ETRs across sectors. The results indicate that companies from trading and services, properties and construction sectors face higher ETRs. Overall, this study explains the impacts of tax incentives to corporate ETRs and determinants of corporate ETRs.
\end{abstract}

Index Terms-Tax Planning, Corporate Effective Tax Rates, Statutory Tax Rate and Malaysian Listed Companies.

\section{INTRODUCTION}

Most companies are involved in tax planning extensively with the purpose of reducing their income taxes since the income tax expenses will reduce their profits. In fact, companies likely choose to hire a tax agent with the intention of minimising the taxes they are required to pay (Murphy, 2004). Initially, tax planning is allowed within the tax laws as it is considered as a legal tax avoidance scheme. However, not all companies have the same opportunities to carry out tax planning. That is why only some companies are involved greatly in tax planning, while others are involved moderately. This is due to the factors such as the size of the companies and the capabilities of the companies to undertake tax planning activities. Besides that, the nature of the business

\footnotetext{
${ }^{1}$ Associate Professor
}

activities also influences the opportunity for the companies to be involved in tax planning. Thus, companies within different sectors may be involved differently in tax planning.

In this study, tax planning is proxied by effective tax rates (ETRs). ETR provides a basic summary statistic of tax performance which describes the amount of taxes paid by a company relative to its gross profit (Harris \& Feeny, 2000). In broad terms, ETR is actually a measure of the company's tax burden because it expresses the rate of tax paid on the company income. "ETR has long been used by policy makers and interest groups in tax reform debates, especially those related to corporate tax provisions" (Gupta \& Newberry, 1997, p. 1). ETR becomes a concern in these debates because it summarizes the cumulative effects of various tax incentives. Since there is proof that corporate ETR varies across companies and over time, thus, it has been used as a tool to identify the level of neutrality of the tax system and the characteristics of companies with higher and lower tax burdens. Hence, ETR has also been used as a justification for instituting reform (Harris \& Feeny, 2000).

Hence, the objectives of this study are to examine the level of corporate effective tax rates during the official assessment system tax regime (1993-2000) and self assessment system tax regime (2001-2006); and to examine the determinants of corporate ETRs of Malaysian public listed companies during both tax regimes. Hence, this study is going to answer the following questions:

1) What are the level of corporate ETRs during official assessment system tax regime and self assessment system tax regime?

2) What are the determinants of corporate ETRs during official assessment system and self assessment system tax regimes?

\section{LITERATURE REVIEW}

\section{A. Corporate Tax System}

In line with the global tax reforms, tax reforms in Malaysia mainly focused on corporate tax system since Malaysia's income tax revenue mostly came from corporate tax. It contributes almost seventy percent of the total income tax revenue to the government (Rohaya, Nor'Azam and Bardai, 2008). This shows that Malaysia largely depends on corporate income tax revenue for public expenditure. One of the strategies of tax reform implemented by this country is the continuous reduction in the corporate statutory tax rates, 
that is from $40 \%$ in 1988 to $28 \%$ in 2006 . In addition, various tax incentives have been introduced to promote the economic growth and to encourage people to be involved in business activities (Rohaya et al., 2008). Examples of tax incentives given are investment tax allowance, double deduction of expenses, pioneer status, exemption of import duties and sales tax and many more.

Basically, the Inland Revenue Board of Malaysia (IRBM) has two ways of assessing a taxpayer's liability which are the official assessment system and the self assessment system. In the previous tax regime, i.e prior to 2001, the official assessment system was adopted. Currently, income tax is assessed according to the self assessment system.

\section{B. Effective Tax Rates and Corporate Attributes}

Relationship between the ETR and size and ETR and profitability are mostly inconsistent across studies. The relation between ETR and company size has became a concern and it has arisen in literature in most ETR studies. This is because of two different points of view related to the issue of company size. They are political cost theory and political power theory. Furthermore, most previous studies such as Derashid and Zhang (2003), Adhikari et al. (2006) and Rohaya et al. (2008) found a negative relationship between ETR and ROA. It indicated that highly profitable companies bear lower income tax burdens since they utilized tax incentives and other tax provisions to reduce their taxable income which would result in a lower ETR.

Additionally, researchers generally found a negative relationship between ETR and leverage (e.g, Gupta \& Newberry, 1997; Buijink \& Janssen, 2000; Adhikari et al., 2006; and Richardson \& Lanis, 2007). This means that companies with higher leverage, that is with more debts, faced lower ETR because interest expenditure was tax-deductible which resulted in a lower taxable income. Regarding the association between ETR and capital intensity, most studies found that the ETR is negatively associated with capital intensity. Gupta and Newberry (1997) revealed the evidence that companies with a larger proportion of fixed assets tended to have lower ETR because of the provisions of capital allowance. In addition, almost all studies on ETR found that the ETR is positively related to inventory intensity. The result indicated that inventory-intensive companies had higher ETR.

\section{Methodology}

\section{A. Sample Selection}

The data used in this study are taken from the Thomson datastream. The sample consists of companies from nine sectors listed on Bursa Malaysia, which includes industrial products, consumer products, trading and services, properties, plantation, construction, technology, infrastructure and hotel. The sample data are collected for a 14 years period from 1993 to 2006. The period for official assessment system tax regime was eight years, i.e 1993-2000. However, the sample data in 1999 were removed since the year 1999 was declared as a waiver year (tax holiday year) for all taxpayers. While, the period for the self assessment system tax regime was six years, i.e 2001 to 2006.

\section{B. Measurement of Effective Tax Rates}

This study examines corporate ETRs as a proxy of corporate tax planning. Corporate ETRs basically assesses the tax performance of firms. Thus, it is the best measure to evaluate the actual corporate tax burdens. Previous studies have used various methods for measuring corporate ETRs, where the numerator was the measure of the company's tax liability and and the denominator was the measure of its income. As for this study, current-based ETR is used. It is defined as a ratio of current income tax expense (total income tax expense minus deferred tax expense) divided by pretax income.

\section{Data Filtering and Recoding}

In the process of data filtering, companies with a negative pretax income are removed from the sample because a negative income create tax saving. This tax saving will bring down the company's ETR in different years due to the carry-forward provision provided in the tax laws. Then, data recoding is performed on the calculated ETR. In the study conducted by Rohaya et al. (2008), the ETR is recoded as follows. First, companies with negative tax expenses which produced a negative ETR were recoded as ' 0 '. Second, companies with an ETR above $100 \%$ i.e the companies tax expense exceeded the pretax income were recorded as ' 100 '. The process of data recoding is necessary since the ETR does not have any economic meaning and can distort the findings in the case when its denominator is zero or negative.

\section{Empirical Model and Variable Definitions}

The empirical analysis in this study uses the following general multivariate model. The ETR model estimated for current-based ETR is as follows:

\section{ETR $_{t}=\beta 0+\beta 1 S I Z E_{t}+\beta 2$ ROA $_{t}+\beta 3$ LEV $_{t}+\beta 4$ CAPINT $_{t}$ $+\beta_{\text {IINVINT }}+$ B6SECTORDummy $_{t}+$ $\beta 7$ YEARDummy $_{t}+\beta 8 R E G D u m m y_{t}+\varepsilon_{t}$}

ETR refers to current-based ETR. Current-based ETR is measured as current income tax expense (income tax expense minus deferred tax expense) divided by pretax income, $\beta 0$ is the intercept or constant; $\beta 1$ SIZE is the company size, measured as log of total sales; $\beta 2 \mathrm{ROA}$ is return on assets, measured as pretax income divided by total assets; $\beta 3 \mathrm{LEV}$ is the firm leverage, measured as total debts divided by total assets; $\beta 4$ CAPINT is capital intensity, measured as fixed assets (property, plant and equipment) divided by total assets; $\beta 5$ INVINT is inventory intensity, measured as inventory divided by total assets; $\beta 6$ SECTORDummy is the sector dummy for industrial products, consumer products, trading and services, properties, plantation, construction, technology and infrastructure; $\beta 7$ YEARDummy is the year dummy for 1993 to 2006; $\beta 8$ REGDummy is the tax regime dummy for official assessment system regime and self assessment system regime; $\varepsilon$ is an error term; $t$ is the firm-years between 1993 to 2006. 


\section{EMPIRICAL RESULTS}

\section{A. Descriptive Statistics and Univariate Analysis}

Table 1 presents descriptive statistics for statutory tax rates (STR) and current-based ETR. During official assessment system (OAS) regime, the mean for STR is $29.5 \%$. While, the mean for current-based ETR is $24 \%$. Further, during self assessment system (SAS) regime, the mean for STR is $28 \%$. While, the mean for current-based ETR is $21.1 \%$. The standard deviations of the current-based ETR during OAS and SAS tax regimes (15.5\% and $16.9 \%$ respectively) revealed significant variations in the ETR between companies in the sample. As the mean for the current-based ETR was below the mean for STR during both tax regimes, thus it is proven that the Malaysian public listed companies are involved in tax planning activities during the OAS and SAS tax regime. By looking at the divergence between current-based ETR and STR, the results revealed that the divergence was greater during SAS regime, thus companies are involved in tax planning more aggressively during that time as compared to OAS regime.

TABLE 1: DESCRIPTIVE STATISTICS FOR STATUTORY TAX RATE (STR) AND CURRENT-BASED ETR

\begin{tabular}{lrc}
\multicolumn{3}{c}{ AND CURRENT-BASED ETR } \\
& STR & Current-based ETR \\
& $\%$ & $\%$ \\
OAS: 1993-2000 & & 24.0 \\
Mean & 29.5 & 25.5 \\
Median & 30.0 & 15.5 \\
Standard Deviation & 1.8 & 0 \\
Minimum & 28.0 & 100.0 \\
Maximum & 34.0 & 520 \\
Firm-years & 520 & \\
SAS: 2001-2006 & & 21.1 \\
Mean & 28.0 & 21.0 \\
Median & 28.0 & 16.9 \\
Standard Deviation & 0 & 0 \\
Minimum & 28.0 & 100.0 \\
Maximum & 28.0 & 1549 \\
Firm-years & 1549 & \\
Pool: 1993-2006 & & 21.8 \\
Mean & 28.4 & 22.2 \\
Median & 28.0 & 16.6 \\
Standard Deviation & 1.1 & 0 \\
Minimum & 28.0 & 100.0 \\
Maximum & 34.0 & 2069 \\
Firm-years & 2069 &
\end{tabular}

Note :

Variable definition is as follows:

$\mathrm{ETR}=$ current tax expense (total tax expense minus deferred tax expense) pretax income

Figure 1 depicts the mean of the current-based ETR for both tax regimes. Based on the chart, it revealed that the current-based ETR (24.7\%) during the OAS regime was higher than the current-based ETR (21.1\%) during the SAS regime. Typically, companies with higher ETR paid higher taxes than the companies with lower ETR. In addition, it indicated that companies with a much higher ETR are involved less aggressive in tax planning as compared to the companies with a much lower ETR. Hence, based on the results, it showed that companies undertook more aggressive tax planning during SAS regime than during the OAS regime due to the much lower ETR during the SAS regime. This is because of supreme utilisation of tax incentives by companies during SAS regime.

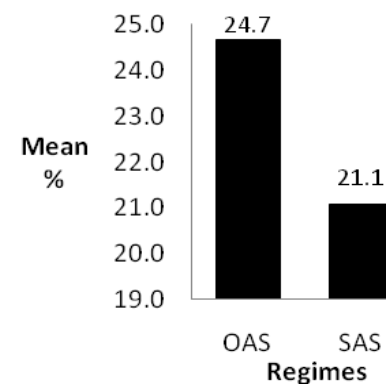

Figure 1: Mean for Current-based ETR by Regimes

\section{B. Regression Results}

The regression results are presented in Table 2. The result revealed that the current-based ETR was positively associated with size during both the OAS and SAS regimes. It indicated that larger companies faced higher income tax burdens, therefore supporting the political cost theory. The same result was observed for pool sample where in overall, there was a positive association between current-based ETR and size at the $1 \%$ level. In addition, there was a negative relationship between current-based ETR and ROA during SAS regime at the $1 \%$ level.. The negative relationship indicated that more efficient and highly profitable companies faced lower tax burdens. The possible reason was that profitable companies managed to take advantage from the availability of tax incentives and other tax provisions to lower their ETR. The result for pool sample was also similar where the current-based ETR was negatively related to ROA at the $1 \%$ level.

Then, the result from regression analysis showed that current-based ETR was negatively associated with leverage during OAS and SAS regimes. The results indicated that companies with higher leverage had lower ETR. This suggested that levered companies benefited from interest tax deductible expenses which further reduced their taxable income. The similar result was observed for pool sample where in overall, there was a negative association between current-based ETR and leverage at the 1\% level. Moreover, as revealed in the Table 4, there was a negative relationship between current-based ETR and capital intensity during OAS and SAS regimes. The negative association revealed that the companies with a larger proportion of fixed assets tended to have lower ETRs. This was due to the tax preferences where the capital-intensive companies benefited from high capital allowance on the fixed assets which led to a lower taxable income. The result for pool sample was similar where the current-based ETR was negatively related to capital intensity at the $1 \%$ level.

Lastly, the current-based ETR was positively associated with inventory intensity during the SAS regime at the 5\% level. The positive association indicated that the inventory-intensive companies faced higher ETR. This is because, unlike capital-intensive companies which could enjoy tax preferences, the inventory-intensive companies did not have those tax shields. Further, with respect to the result for pool sample, there was a significant and positive relationship between current-based ETR and inventory intensity at the $10 \%$ level. 
Model:

TABLE 2: REGRESSION RESULTS

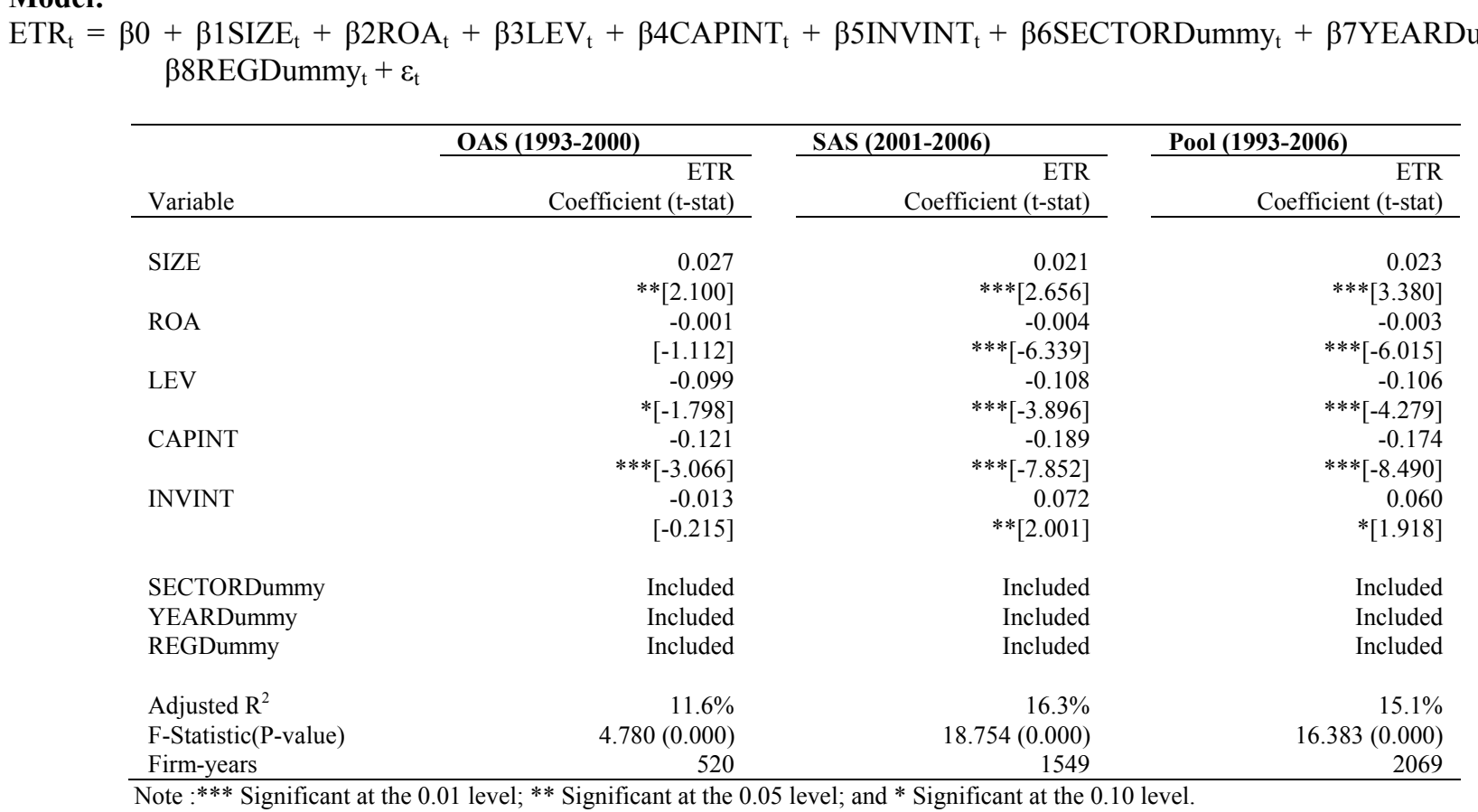

\section{Sector Analysis}

Figure 2 depicts the level of current-based ETR for each sector during both tax regimes. As can be seen, the industrial products, trading and services, consumer products, plantation, technology and properties sectors reported a much lower current-based ETR during the SAS regime. This result showed that the companies within those sectors were involved in more aggressive tax planning during SAS regime. Hence, it proved that various tax incentives that were offered during SAS regime have given the companies the chances to engage in more aggressive tax planning. While, the other two sectors that were construction and infrastructure sectors reported a much higher current-based ETR during the SAS regime. Thus, it revealed that the companies within the two sectors were involved in less aggressive tax planning during SAS regime. This is may be because of limited tax incentives available to them during SAS tax regime.

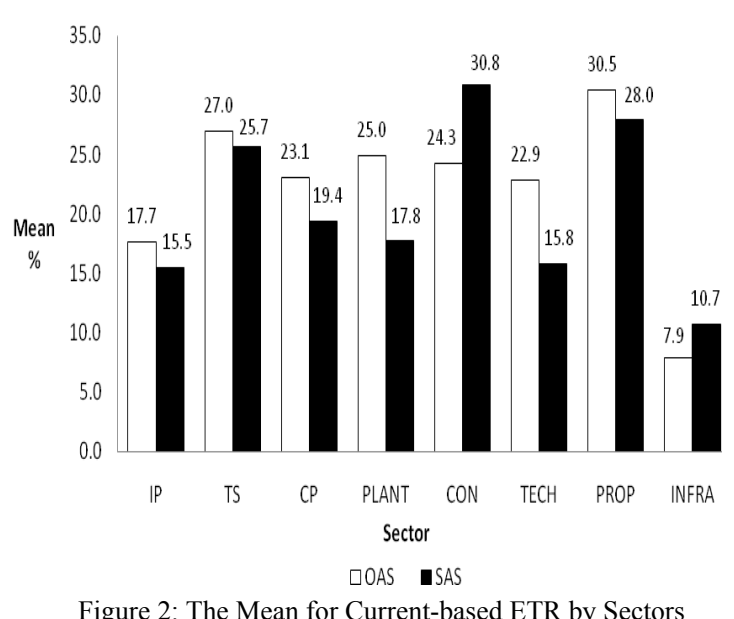

During Official Assessment System and Self Assessment Sytem Regimes

\section{CONCLUSIONS}

This study revealed that the Malaysian corporate tax system indeed provided a substantial amount of tax incentives to companies, thus encouraging the companies to engage in aggressive tax planning. Moreover, the difference in ETRs between sectors suggested that the tax incentives only benefited companies within the particular sectors. Therefore, there is an issue of non-neutrality of the corporate tax system. These findings could provide suggestions to tax authorities to undertake tax auditing and investigation to trace illegal tax planning activities. Since this study found that the sampled companies were involved in aggressive tax planning, thus future research should investigate the tax planning strategies undertake by companies, as well as the relationship between ETRs and corporate governance.

\section{REFERENCES}

[1] Adhikari, A., Derashid, C. and Zhang, H. (2006). Public policy, political connections, and effective tax rates: Longitudinal evidence from Malaysia. Journal of Accounting and Public Policy, 25, 574-595.

[2] Banking and Financial Institute Act, 1989.

[3] Buijink, W. and Janssen, B. (2000). Determinants of the variability of corporate effective tax rates (ETRs): Evidence for the Netherlands. MARC Working Paper, University of Maastricht.

[4] Choong Kwai Fatt, (2008). Malaysian Taxation, Principles and Practice, 14th Edition, InfoWorld, Kuala Lumpur.

[5] Derashid, C. and Zhang, H. (2003). Effective tax rates and the "industrial policy" hypothesis: Evidence from Malaysia. Journal of International Accounting, Auditing \& Taxation, 12, 45-62.

[6] Generally Adopted Accounting Principles (GAAP)

[7] Gupta, S. and Newberry, K. (1997). Determinants of the variability in corporate effective tax rates: Evidence from longitudinal data. Journal of Accounting and Public Policy, 16, 1-34.

[8] Harris, M. N. and Feeny, S. (2000). Habit persistence in effective tax rates: Evidence using Australian tax entities, Working Paper, University of Melbourne.

[9] Income Tax Act (ITA), 1967

[10] Lembaga Hasil Dalam Negeri, http://www.hasil.gov.my 
[11] Murphy, K. (2004). Aggressive tax planning: Differentiating those playing the game from those who don't. Journal of Economic Psychology, 25, 307-329.

[12] Richardson, G. and Lanis, R. (2007). Determinants of the variability in corporate effective tax rates and tax reform: Evidence from Australia. Journal of Accounting and Public Policy, 26, 689-704.

[13] Rohaya, M. N., Nor'Azam, M. and Bardai, B. (2008). Corporate effective tax rates: A study on Malaysian public listed companies. Malaysian Accounting Review, 7(1), 1-20. 